\title{
DEGUONIES ĮSOTINIMO ŠLAUNIES RAUMENYJE IR ŠIRDIES FUNKCINIŲ RODIKLIUU KAITA ATLIEKANT PAKOPOMIS DIDINAMĄ KRŪVİ VELOERGOMETRU
}

\author{
Birutė Miseckaite் $^{1}$, Vytautas Poškaitis ${ }^{2}$, Kristina Poderyte் ${ }^{2}$, Alfonsas Vainoras ${ }^{2}$, \\ Julija Andrejeva ${ }^{1}$, Jonas Poderys ${ }^{1,2}$ \\ Lietuvos kūno kultūros akademija ${ }^{1}$, Kauno medicinos universitetas ${ }^{2}$, Kaunas, Lietuva
}

Birutė Miseckaitė. Biomedicinos mokslų magistrè. Lietuvos kūno kultūros akademijos Kineziologijos laboratorijos mokslo darbuotoja. Mokslinių tyrimų kryptis — organizmo funkcinès būklès kompleksinis vertinimas.

\section{SANTRAUKA}

Tyrimo tikslas - išsiaiškinti, ar audiniu infraraudonosios spektroskopijos metodu registruojami rodikliai leidžia tiksliau vertinti širdies ir kraujagysliu sistemos funkcinę būklę, t. y. centriniu ir periferiniu, kraujotakos rodikliu kitimo sqsajas veloergometrinio krüvio metu.

Tirti 27 savanoriai sveiki vyrai: amžius $-32,7 \pm 1,8$ m.; ügis $-180,9 \pm 0,03 \mathrm{~cm}$; KMI $-25,3 \pm 0,6$. Tiriamieji turëjo atlikti pakopomis didinama veloergometrini krūvi, kurio metu registruojama elektrokardiograma, matuojamas arterinis kraujospūdis ir deguonies isotinimas šlaunies raumenyje (m. vastus lateralis).

Tyrimo rezultatai parode, kad registruojama deguonies isotinimo kaita priklauso nuo fizinio krūvio sunkumo. Deguonies isotinimo kaitos vertinimas atliekant pakopomis didinama krūvi veloergometru rodo periferiniu kraujagysliu vazodilatacijos ar vazokonstrikcijos efektus. Didinant fizinio krūvio intensyvuma iki tol, kol tiriamasis nebepajegia jo atlikti, deguonies isotinimo kreives kinta priklausomai nuo tiriamojo funkcinio parengtumo. Tarp didesnio darbingumo tiriamuju nebuvo užregistruota reikšmingu elektrokardiogramos ST segmento depresijos pokyčiu, o deguonies isotinimo kreivè, atliekant pakopomis didinama krūvì, vis krito. Tarp mažesni krūvì tegebejjusiu atlikti tiriamuju deguonies isotinimo kreivè pradžioje krito, o kilti pradèjo tada, kai krūvis pasidarydavo tiriamajam per sunkus, ir elektrokardiograma užfiksuodavo reikšminga ST segmento depresijos didejimq. Taigi deguonies isotinimo kreivès kilimas (antra fazé) rodo širdies darbingumo ribq.

Apibendrinant galima teigti, kad infraraudonosios spektroskopijos metodu registruojami rodikliai leidžia tiksliau vertinti širdies ir kraujagysliu sistemos funkcinę büklę, t. y. centriniu ir periferiniu, kraujotakos reguliavimo rodikliu sqajajas.

Raktažodžiai: darbingumas, širdies ir kraujagysliu sistema, deguonies isotinimas.

\section{IVADAS}

$\mathrm{P}$ arengtumo ir funkcinès būklès vertinimas yra labai svarbus darbo etapas planuojant sportininko treniruotès krūvius, sudarant sveikatos stiprinimo programas. Sportuojančiu asmenų parengtumui ir funkcinei būklei ịvertinti taikomi fizinio krūvio testai. Plačiai taikomi pakopomis didinami krūviai veloergometru, registruojant elektrokardiogramą (EKG) ir matuojant arterinio kraujo spaudimo (AKS) kitimą (Vainoras, 1996; Poderys, 2000; Žumbakyte, 2006 ir kt.). Deja, tokių tyrimų metu raumenų kraujotakos ar deguonies isotinimo aktyviuosiuose raumenyse ypatybès retai vertinamos. Pastaruoju metu atsirado galimybė neinvaziniu audinių spektroskopijos metodu nenutrūkstamai registruoti deguonies kiekio pokyčius dirbančiame raumenyje (Mancini ir kt., 1994; Valic et al., 2006). Audiniu infraraudonosios spektroskopijos naudojamos šviesos bangos ilgis yra $650-1000 \mathrm{~nm}$. Infraraudonieji spinduliai lengvai parsiskverbia pro odą ir poodinius audinius. Audinio prisotinimas deguonimi nustatomas pagal šviesos kiekị, kuri absorbuoja ir parodo hemoglobinas. Šviesa sąlygiškai lengvai prasiskverbia pro audinius, tačiau deguoni 
atidavęs ir deguonimi prisotintas hemoglobinas absorbuoja skirtingo ilgio šviesos spindulius.

Tyrimo tikslas - išsiaiškinti, ar audinių infraraudonosios spektroskopijos metodu registruojami rodikliai leidžia tiksliau vertinti širdies ir kraujagysliu sistemos funkcinę būklę, t. y. centrinių ir periferinių, kraujotakos rodiklių sąsajas.

\section{METODIKA}

Buvo tiriami 27 savanoriai sveiki vyrai: amžius - 32,7 $\pm 1,8 \mathrm{~m}$.; ūgis $-180,9 \pm 0,03 \mathrm{~cm}$; KMI $-25,3 \pm 0,6$. Visi tiriamieji atliko pakopomis didinamą fizini krūvi veloergometru, t. y. pradèdavo minti veloergometra $50 \mathrm{~W}$ apkrova (60 apsukų per minutę dažniu) ir kas minutę didino krūvị po 50 W. Krūvị tiriamieji tęsdavo tol, kol nebepajègdavo jo atlikti arba iki pirmu klinikiniu požymių išryškèjimo pagal AHA (Amerikos širdies asociacijos) rekomendacijas. Po krūvio tiriamieji tris minutes ilsèjosi sèdèdami ant veloergometro.

Širdies funkciniams rodikliams vertinti buvo naudojama Kauno medicinos universiteto Kardiologijos institute sukurta elektrokardiogramos analizès sistema „Kaunas-krūvis“. Krūvio metu ir pirmas tris atsigavimo minutes registravome 12 standartinių EKG derivacijų. Buvo analizuojami šie rodikliai: širdies susitraukimų dažnis, ST segmento depresija. EKG analizès sistema apskaičiavome ŠKS funkcinių rodiklių visų 12 EKG atvadų per $10 \mathrm{~s}$ registracijos intervalo reikšmių vidurkius. AKS buvo matuojamas prieš krūvị, kiekvienos krūvio pakopos pabaigoje ir pirmas tris atsigavimo minutes.
Krūvio metu ir po jo deguonies isotinimo $\left(\mathrm{StO}_{2}\right)$ kaita raumenyje buvo vertinama neinvaziniu artimosios infraraudonosios spektroskopijos būdu, naudojant vieną audinių spektrometrą (In Spectra Tissue Spectrometer, Standart System Model 325) ir $25 \mathrm{~mm}$ optini laidą, sujungtą su sensityviniu fotodetektoriumi (Hutchinson Technology, Hutchinson, Minnesota USA), davikli tvirtinant ant šlaunies keturgalvio raumens lateralinès galvos. $\mathrm{StO}_{2}$ matavimai buvo atliekami kas 2,5 s, registruojant rodiklių kaitą krūvio metu ir pirmas 3 minutes po krūvio.

\section{REZULTATAI}

Širdies ir kraujagyslių sistemos funkcinių rodikliu kaita atliekant kas minutę pakopomis didinamą krūvị veloergometru pateikta lentelèje. Didžiausi registruotų rodikliu pokyčiai buvo nustatyti tada, kai tiriamieji atlikdavo $250 \mathrm{~W}$ galingumo krūvị. Tuo metu širdies susitraukimų dažnis sieké 162,6 \pm 5,4 tv. / min; ST segmento depresija $-0,48 \pm 0,11 \mathrm{mV}$, o $\mathrm{StO}_{2}$ rodiklis šlaunies raumenyje buvo mažiausias tiriamiesiems pasiekus $200 \mathrm{~W}$ darbo galinguma, t. y. 37,1 $\pm 4,7 \%$. Pasiekus ribini $300 \mathrm{~W}$ krūvị, visi rodikliai lyg ir pradejo mažèti: ŠSD $-140,3 \pm 12,1$ tv. / min; ST segmento depresija $--0,03 \pm 0,15 \mathrm{mV}, \mathrm{StO}_{2}$ padidejo iki $44,7 \pm 9,7 \%$.

Atsigavimo po krūvio metu buvo užregistruotas spartus rodikliu grižimas ì pradini lygi, tik per tris atsigavimo minutes AKS ir dauguma EKG rodiklių negrį̌zo i ji. EKG ST segmento depresija jau nesiskyrè nuo pradinių reikšmių, o

\begin{tabular}{|c|c|c|c|c|c|c|}
\hline \multirow{2}{*}{\multicolumn{2}{|c|}{ Tyrimo etapai }} & \multirow{2}{*}{ ŠSD, tv. / min } & \multirow{2}{*}{$\begin{array}{l}\text { ST segmento } \\
\text { depresija, mV }\end{array}$} & \multirow{2}{*}{$\mathrm{StO}_{2}, \%$} & \multicolumn{2}{|c|}{ AKS (mmHg) } \\
\hline & & & & & Sistolinis & Diastolinis \\
\hline \multicolumn{2}{|c|}{ Prieš krūvị } & $86,5 \pm 2,4$ & $-0,08 \pm 0,01$ & $66,3 \pm 3,3$ & $124,4 \pm 1,7$ & $82,2 \pm 1,5$ \\
\hline \multirow{6}{*}{ 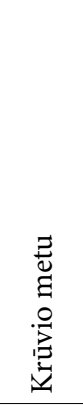 } & $50 \mathrm{~W}$ & $104,3 \pm 2,3$ & $-0,13 \pm 0,02$ & $59,3 \pm 3,5$ & $139,2 \pm 2,2$ & $75,8 \pm 1,9$ \\
\hline & $100 \mathrm{~W}$ & $120,2 \pm 2,4$ & $-0,218 \pm 0,04$ & $48,6 \pm 3,5$ & $153,3 \pm 2,2$ & $70,8 \pm 2,3$ \\
\hline & $150 \mathrm{~W}$ & $138,6 \pm 2,8$ & $-0,39 \pm 0,10$ & $37,6 \pm 4,1$ & $175,3 \pm 2,9$ & $71,4 \pm 2,4$ \\
\hline & $200 \mathrm{~W}$ & $154,8 \pm 2,8$ & $-0,40 \pm 0,07$ & $37,1 \pm 4,7$ & $193,1 \pm 3,7$ & $64,8 \pm 4,2$ \\
\hline & $250 \mathrm{~W}$ & $162,6 \pm 5,4$ & $-0,48 \pm 0,11$ & $39,7 \pm 6,8$ & $202,5 \pm 5,6$ & $56,4 \pm 7,28$ \\
\hline & $300 \mathrm{~W}$ & $140,3 \pm 12,1$ & $-0,03 \pm 0,15$ & $44,7 \pm 9,7$ & $178,9 \pm 8,3$ & $54,3 \pm 7,9$ \\
\hline \multirow{3}{*}{ 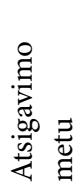 } & $1 \mathrm{~min}$ & $130,1 \pm 3,8$ & $-0,23 \pm 0,04$ & $76,3 \pm 2,9$ & $162,7 \pm 3,3$ & $62,8 \pm 3,5$ \\
\hline & $2 \min$ & $120,9 \pm 3,1$ & $-0,22 \pm 0,04$ & $80,0 \pm 2,7$ & $153,9 \pm 3,6$ & $63,3 \pm 2,6$ \\
\hline & $3 \mathrm{~min}$ & $112,44 \pm 3,4$ & $-0,24 \pm 0,05$ & $84,32 \pm 2,5$ & $139,9 \pm 3,7$ & $66,5 \pm 2,3$ \\
\hline
\end{tabular}


Pav. Individuali tiriamųjų deguonies kiekio kaita šlaunies keturgalvio raumens lateralinėje galvoje, atliekant pakopomis didinamą krūvị veloergometru
Pastaba. $1-\mathrm{StO}_{2}$ mažeja iki krūvio pabaigos; 2 - iveikiant paskutines krūvio veloergometru pakopas $\mathrm{StO}_{2}$ pradeda didèti.

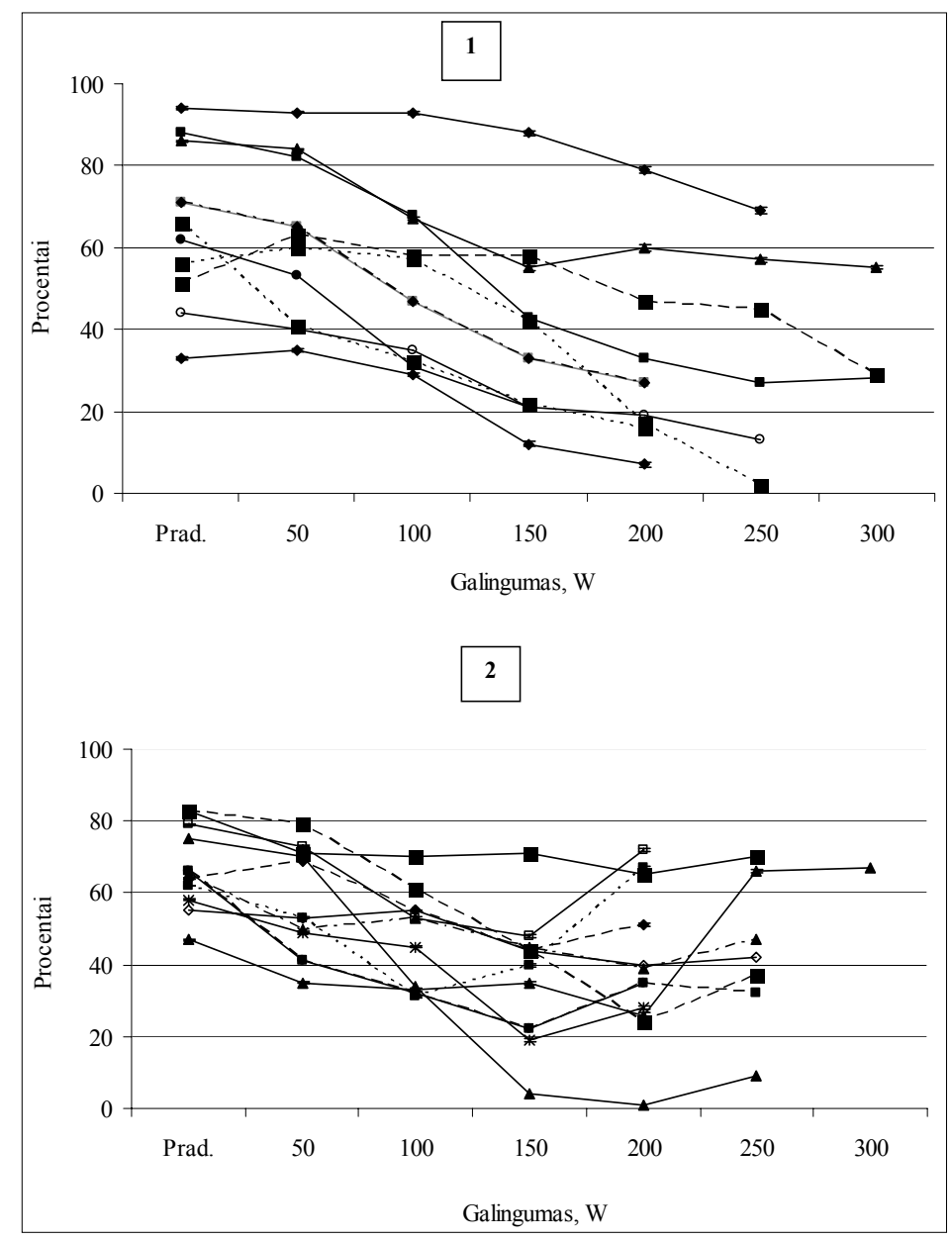

krūvị ties 206,7 \pm 9,6 W galingumo riba. Skirtumas tarp grupių statistiškai patikimas $(\mathrm{p}<0,05)$.

\section{REZULTATU APTARIMAS}

Atsiradus galimybei fizinio krūvio metu netiesioginiais metodais registruoti deguonies isotinimo kaitos ypatybes raumenyje, padaugejo mokslinių studijų šia tema, bet $i$ daugeli klausimų vis dar neatsakyta. Nèra aišku, kaip ir kokia seka vyksta atskiri procesai, kuomet vis didinant atliekamo krūvio intensyvumą prasideda širdies funkcijos apribojimai. Šio tyrimo metu sinchroniškai registruojant EKG ir $\mathrm{StO}_{2}$ rodiklius, buvo ieškoma sąsajų. Lenteleje pateikti $\mathrm{StO}_{2}, \mathrm{EKG}$ ir AKS rodiklių vidurkiai yra idomūs, bet neatskleidžia tų centrinių ir periferinių, kraujotakos reguliavimo mechanizmų sąsajų, kurios vis keičiasi kintant subjektyviam fizinio krūvio sunkumui iki maksimalaus. Todèl vertinant tyrimo rezultatus buvo išskirtos individualios rodikliu kaitos fazès, ịvertinti rodiklių kaitos greičiai ir ju tarpusavio ryšiai. Šie vertinimai atskleidè tokius dèsningumus: 1) didesnis darbingumas (iveikè daugiau krūvio pakopų) buvo tų tiriamujų kurie nepatyrè funkcinių išeminių reiškinių miokarde viso kai jis vidutiniškai pasiekdavo 245,0 $\pm 11,7 \mathrm{~W}$ galingumą. Antros grupès tiriamieji baigdavo 
pakopomis didinamo krūvio metu; 2) didejjant atliekamo krūvio galingumui, $\mathrm{StO}_{2}$ dirbančiame raumenyje mažèjo, tačiau kada tiriamieji išugdè krūvio galingumą, artimą ribiniam, t. y. $250-300 \mathrm{~W}$, kai kurių tiriamujų $\mathrm{StO}_{2}$ kreivè pradejjo kilti. Tokią šio rodiklio kaitą galejjo lemti periferinès kraujotakos kaitos ypatumai, taip pat glaudžios sąsajos tarp periferiniu ir centrinių kraujotakos reguliavimo mechanizmų. Kitų mokslininkų (Šilinskas, Poderys, 1999; Poderys, 2000) atlikti tyrimai vertinant raumenų kraujotakos kaitos ypatybes veloergometrinio krūvio metu parodè, kad didinant fizinio krūvio intensyvumą tol, kol tiriamasis nebepajègia jo atlikti, pasireiškia periferinių kraujagyslių vazidilatacija ir stipriai suintensyveja kraujotaka blauzdoje. Tiriamajam atliekant paskutines sunkiausiai įveikiamas krūvio pakopas, galima nustatyti širdies raumens darbingumo ribą ir kompensaciniu mechanizmu isitraukimo procesus. Šio tyrimo rezultatai parode, kad $\mathrm{StO}_{2}$ kaitos antra fazè buvo užregistruota tik tarp tų tiriamujų, kurie patyrè funkcinius išeminius reiškinius miokarde, ir atvirkščiai — ji nenustatyta tarp tų, kurių reikšmingas ST segmento depresijos didejjimas neužregistruotas. Elektrokardiogramos ST segmento dislokacija krūvio metu siejama su išeminių reiškinių atsiradimu miokarde, o tokius trumpalaikius ST segmento nuokrypius siūloma laikyti funkciniais išeminiais pokyčiais (Yazigi et al., 1998; Jernberg et al., 1999; Vainoras, 1996, 2002). Funkcinių išeminių reiškinių atsiradimas ir didejjimas fizinio krūvio metu gali būti organizmo darbingumo, parengtumo ir funkcinès būklès rodiklis.

Sisteminès kraujotakos reguliaciniai mechanizmai palaiko slègio gradientą, būtiną norint palaikyti reikiamą kraujotakos intensyvumą dirbančiuose raumenyse. Širdies darbo ir bendrojo periferinio pasipriešinimo rodikliu kitimas yra tarpusavyje susiję (Ahlborg et al., 1996). Lokalioji kraujotaka efektyviausiai reguliuojama tada, kai yra keičiamas hidrodinaminis kraujagysliu pasipriešinimas, t. y. keičiamas ju spindis (Schmidt, Thews, 1996). Todèl reikšmingas AKS rodiklis yra pulsinis slègis, kurio kaita atliekant pakopomis didinamą krūvị veloergometru koreliaciniais ryšiais buvo susijusi su audinių deguonies prisotinimo kaita. Kai krūvis didejo ir ji tiriamajam buvo vis sunkiau atlikti, koreliacija tarp pulsinio AKS ir $\mathrm{StO}_{2}$ kaitos vis didejo. Padidejusi baroreceptorių impulsacija slopina simpatinę eferentaciją — ivyksta vazodilatacija, mažejja kraujagysliu periferinis pasipriešinimas (Halliwill et al., 1996; Žemaityte, 1997; Krieger et al., 2001).

Funkcinius kraujotakos rodiklius nuolatos registruoja receptoriai, išdèstyti įvairiose širdies ir kraujagysliu sistemos vietose. Aferentiniais impulsais iš šiu receptorių siunčiama informacija patenka i pailgose smegenyse esančius vazomotorinius centrus, iš kuriu eferentinèmis skaidulomis siunčiamais impulsais yra reguliuojamas širdies darbas ir ivvairių kūno kraujagyslių tonusas. Tyri-

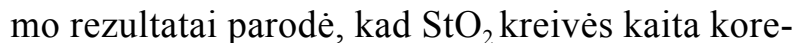
liuoja su fizinio krūvio sunkumo ir individualiais ST segmento kaitos rodikliais. Tai leidžia aiškiau suprasti centriniu ir periferinių, kraujotakos rodiklių sąsajas.

\section{IŠVADOS}

1. Pakopomis didinant krūvị, deguonies ísotinimas aktyviuose raumenyse mažeja, o kai krūvis pasidaro per sunkus, dalis tiriamuju patiria vis didejjančius funkcinius išeminius reiškinius miokarde, keičiasi deguonies įsotinimo kreivè, kuri rodo širdies darbingumo ribą.

2. Infraraudonosios spektroskopijos metodu registruojami rodikliai leidžia tiksliau vertinti širdies ir kraujagyslių sistemos funkcinę būklę, t. y. centrinių, periferinių ir kraujotakos rodiklių sąsajas.

\section{LITERATŪRA}

Ahlborg, G., Ottosson-Seeberger, A., Hemsen, A., Lundberg, J. M. (1996). Central and regional hemodynamic effects during infusion of Big endothelin-1 in healthy humans. Journal of Applied Physiology, 80 (6), 19211927.

Halliwill, J. R., Taylor, J. A., Eckberg, D. L. (1996). Impaired sympathetic vascular regulation in humans after acute dynamic exercise. Journal of Physiology, 15, 495 (Pt 1), 279-288.

Jernberg, T., Lindahl, B., Wallentin, L. (1999). ST-segment monitoring with continuous 12-lead ECG improves early risk stratification in patients with chest pain and ECG nondiagnostic of acute myocardial infarction. American College of Cardiology, 34 (5), 1413-1419.

Krieger, E. M., Da Silva, G. J., Negrao, C. E. (2001). Effects of exercise training on baroreflex control of the cardiovascular system. Annual New York Academic Science, 940, 338-347.

Poderys, J. (2000). Širdies ir kraujagysliu sistemos greitosios ir letosios adaptacijos savybès, atliekant fizinius pratimus: habilitacinis darbas. Kaunas.

Schmidt, R. F., Thews, G. (1996). Human physiology. 2nd edition. London. 
Šilinskas, V., Poderys, J. (1999). Asmenų, adaptuotų prie greitumo jègos ir ištvermès pobūdžio fizinių krūvių, blauzdos raumenų kraujotaka funkcinių mėginių ir fizinio krūvio metu. Sporto mokslas, 2 (16), 22-25.

Vainoras, A. (2002). Functional model of human organism reaction to load-evaluation of sportsman training effect. Ugdymas. Küno kultūra. Sportas, 3 (44), 88-93.

Vainoras, A. (1996). Investigation of the heart repolariztion process during rest and bicycle ergometry (100-lead and standard 12-lead ECG data): Synopsis of a Doctor of Science Habil. Kaunas.

Valic, Z., Palada, I., Bakovic, D., Valic, M., Dujic, Z. (2006). Muscle oxygen supply during cold face immersion in breath-hold divers and controls. Aviation, Space, and Environmental Medicine, 77 (12), 1224-1229.

Yazigi, A., Richa, F., Gebara, S. et al. (1998). Prognostic importance of automated ST-segment monitoring after coronary artery bypass graft surgery. Acta Anaesthesiologica Scandinavica, 42 (5), 532-535.

Žemaitytè, D. (1997). Širdies ritmo autonominis reguliavimas: mechanizmai, vertinimas, klinikinè reikšmè. Palanga. P. $50-53,138-141$.

Žumbakytè, R. (2006). Krepšininku ir futbolininku funkcinès büklès ypatybès naudojant integraliojo vertinimo modeli: daktaro disertacijos santrauka. Kaunas: KMU.

\title{
PECULIARITIES OF OXYGEN SATURATION IN MUSCULAR TISSUE AND CARDIOVASCULAR CHANGES DURING THE INCREMENTAL BICYCLE ERGOMETRY
}

\author{
Birutė Miseckaitė ${ }^{1}$, Vytautas Poškaitis ${ }^{2}$, Kristina Poderyte் ${ }^{2}$, Alfonsas Vainoras ${ }^{2}$, \\ Julija Andrejeva ${ }^{1}$, Jonas Poderys ${ }^{1,2}$ \\ Lithuanian Academy of Physical Education ${ }^{1}$, Kaunas University of Medicine ${ }^{2}$,
} Kaunas, Lithuania

\begin{abstract}
The aim of this study was to assess in what sequence various changes in cardiovascular system occur during the incremental increase in workload. A synchronous observation of changes in oxygen saturation $\left(\mathrm{StO}_{2}\right)$ in $\mathrm{m}$. vastus lateralis and changes in 12 leads ECG during the incremental increase in workload every minute were registered. System "Kaunas-load" was employed for the registration and analysis of 12 leads ECG and a InSpectra Standart System Model 325 was used for the registration of changes in $\mathrm{StO}_{2 .}$ Participants of the study were 27 healthy males.

The results obtained in the study showed that the $\mathrm{StO}_{2}$ increased during the incremental increase in workload significantly with every next step of workload. The characteristics of changes in $\mathrm{StO}_{2}$ were closely related to the effects of vascular vasodilatation. When the workload increased much and serious ischemic episodes in cardiac muscle occured the curve of changes of $\mathrm{StO}_{2}$ depended on the functional preparedness of the participant of the study. All participants of the study could be divided into two groups according to the type of changes of $\mathrm{StO}_{2}$ during the workload. The first group demonstrated decrease in curve of $\mathrm{StO}_{2}$ till the end of incremental increase in workload and higher performance abilities, i. e. more exercise steps were performed. The second group demonstrated decrease in the curve of $\mathrm{StO}_{2}$ during workload, which was changed to increase of curve of $\mathrm{StO}_{2}$ at that point of exercising when the significant increase in ST-segment depression was registered. We conclude that the second phase in curve of $\mathrm{StO}_{2}$ during the heavy workload is the sign of limited abilities of cardiac muscle. Assessments of cardiovascular function complemented by data obtained by InfraRed Spectrascophy provides the ability assess the cardiovascular changes during exercising more precisely, i. e. to assess the links between central and peripheral changes in cardiovascular system.
\end{abstract}

Keywords: physical working capacity, cardiovascular system, oxygen saturation.

Gauta $2007 \mathrm{~m}$. vasario $12 \mathrm{~d}$.

Received on February 12, 2007

Priimta $2007 \mathrm{~m}$. balandžio $24 \mathrm{~d}$.

Accepted on April 24, 2007
Birutė Miseckaitė

Lietuvos kūno kultūros akademija

(Lithuanian Academy of Physical Education)

Sporto g. 6, LT-44221 Kaunas

Lietuva (Lithuania)

Tel +370 61221220

E-mail biruseb@gmail.com 